\title{
Hughes reaches out
}

\section{Washington}

AFTER of years of appeals from abroad, the largest private source of research funds in the United States is planning to go international.

The wealthy Howard Hughes Medical Institute (HHMI) has agreed to begin funding research in Canada and Mexico, and hopes to expand across the Atlantic in 1991, officials said last week.

An HHMI external advisory panel will decide the exact amount of the funding and number of grant recipients in Canada and Mexico at a meeting next month, and a formal announcement will be made in April, according to Purnell Choppin, president of HHMI.

The new programme is expected to be the first stage of an international expansion for the foundation, but HHMI officials say that it is too early to pinpoint where the institute's largesse will land next. FETAL CELL TRANSPLANTS

\section{French fetal cell trans- plant operations Paris}

A French national ethics comittee for life sciences and health has overturned its ban on the use of fetal brain tissue grafts for medical treatments.

This means that a team of doctors at the Henri-Mondor hospital in Créteil, south of Paris, will now be able to carry out pilot operations to treat patients suffering from Parkinson's disease.

This kind of treatment is now authorized in some other European countries including Britain, Spain and Sweden, but is allowed in the United States, where there is a powerful anti-abortion lobby, only so long as federal funds are not used.

In October last year, the ethics committee ruled that more research was needed before fetal tissue could be used for this kind of operation. At that time, fetal dopamine-producing cells were used to enhance the effects of adrenal tissue extracted from the patient and reinjected into the area of the brain where dopamine is produced.

This is a very dangerous procedure. But, says Marc Peschanski, a researcher at the Henri-Mondor hospital and co-signatory of a recent appeal to the ethics committee, new research in Sweden has made the operation safer.

According to Peschanski, the ethics committee's 1989 ruling was unsolicited. "We were not even consulted", he says. But when his research team protested, the committee agreed to review its position. Now it is Peschanski's proposed protocol that has led to the ethics committee's about-turn.

Peter Coles
Joseph Perpich, HHMI's vice president for grants, said that the programme was in part a reflection of a "large number of entreaties from abroad", especially the United Kingdom. But a decision on where and when to expand the programme beyond North America will probably not be made until late in 1991, he said.

"We decided to start this on a pilot experimental basis and the logical first choice was our immediate neighbours", Choppin said. Future expansion may be in both the developed and developing world - "anywhere where the best science is going on". Rather than opening the competition to all, HHMI plans to target specific geographic areas. "We're not going to deal with the whole world at the same time", he said.

HHMI spends some $\$ 300$ million (4.5-5 per cent) of its $\$ 6.1$ million total worth each year on basic biomedical research. HIV INFECTION

\section{UK haemophiliacs win compensation} \section{London}

IN A sharp reversal of government policy, John Major, the UK Prime Minister, last week announced that haemophiliacs infected with the AIDS virus through imported blood-clotting factor VIII supplied by the National Health Service will receive a further $£ 42$ million.

David Watters, general secretary of the Haemophilia Society, welcomed the government's implicit admission of legal responsibility (previous payments of $£ 34$ million had been made on an ex gratia basis), but was "very disappointed" that the settlement fell short of the $£ 100$ million the society was campaigning for.

Nevertheless, most haemophiliacs and more than 200 dependents fighting the government for compensation are now expected to accept the settlement, averaging $£ 35,000$ each, and drop their legal action.

About 1,200 British haemophiliacs are now infected with HIV (human immunodeficiency virus), and over 150 have died from AIDS

The government had previously maintained that scientific knowledge in the early 1980 s, when the haemophiliacs became infected, was insufficient for it to be held responsible.

A number of HIV-infected haemophiliacs in the United States have filed negligence suits against individual pharmaceutical companies. But these are unlikely to be successful, as most haemophiliacs have used clotting factor produced by a number of companies (see Nature 347, 319; 27 September 1990). Peter Aldhous
To retain its tax-free status, HHMI distributes most of that in the United States to its special HHMI investigators, mostly university scientists who officially become HHMI employees. But some $\$ 50$ million is also spent annually on grants to other researchers, and all over-seas research support will probably come from that pot. First-year funding to researchers in Canada and Mexico has not yet been decided, but is likely to be in the range of "a few million dollars", Choppin said. The bulk of HHMI's expenditures, however, will probably always be in the United States, he added.

Potential recipients in Canada and Mexico have already been contacted, Typically, HHMI grants are in $\$ 50,000-\$ 100,000$ range.

Choppin said that HHMI is not at present taking applications for other international grants, beyond those for existing programmes to support foreign students in US universities and to send US students abroad.

Christopher Anderson

CANCER RESEARCH

\section{ICRF in row over 'exaggerated' claim} London

AN Imperial Cancer Research Fund (ICRF) fund-raising advertisement carried by several British national newspapers "could be seen as claiming an exaggerated pioneering role" in the development of a breast cancer therapy, says the UK's Advertising Standards Authority (ASA). The ICRF, the largest UK funding body for cancer research, which relies on charitable donations, has rejected the criticism.

A number of medical scientists questioned the claim that an ICRF group at Guy's Hospital, London, pioneered conservation therapy - where iridium implants are used as an alternative to the psychologically distressing treatment of mastectomy.

The technique was first developed by the surgeon Sir Geoffrey Keynes, working in a private London practice in the $1920 \mathrm{~s}$, the complainants argued. The ICRF has no plans to re-use the advertisement, but stands by its content. Keynes's early work was inconclusive, the ICRF says, and the Guy's team played a key role in the largest clinical trial of conservation therapy.

The ASA is a voluntary regulating body set up by the British advertising industry, mostly dealing with objections to misleading claims made for commercial products. When complaints are upheld by independent experts, the authority asks for advertisements to be withdrawn. The ASA took a middle course in the case of the ICRF advertisement, delivering a simple admonishment rather than formally upholding the complaint. Peter Aldhous 